\title{
The Journal of the American Medical Association
}

Published under the Auepices of the Board of Truateos

VoL. LV, No. 24

\section{THE USE OF TYPHOID VACCINES IN TYPHOID FEVER*}

JAMES M. ANDERS, M.D., LI.D.

Professor of Medicine and Clinical Medicine in the Medico. Chirurgical College

\section{PHILADELPHIA}

The vaccine treatment of typhoid fever has been tested in recent years by a number of clinicians with varying results. Fracnkel ${ }^{1}$ was the first to call attention to the subject of the treatment of this disease by vaccine therapy. Since the commencement of the yoar 1909, a considerable number of other witers have reported individual experiences of the use of typhoid vaccines as a means of cure. While the medical profession is not, in any marked degree, enthusiastic in regard to the question, every new remedy or method of treatment that rests on a reasonably secure, scientific basis deserves an extended trial before it is rejected. Certain fundamental principles and facts, which are generally accepted by laboratory experts, should be understood also by the clinician who intends to use vaccines in the treatment of typhoid fever and other diseases. Among these are:

1. The object of vaccine therapy is to induce an active immunity by introducing an added amount of morbific material, so that "by manufacturing an increased amount of the protective bodies, it (the body of the vaceinated person) shall inlibit the growth of the invading organisms, and cut short the disense.":

2. When the Bacillus typhosus undergoes solution in the human organism, endotoxin, to which its pathogenic action is wholly attributable, is set free.

3 . In the process of immunization, both bacteriolysis and phagocytosis play a part. Tmery is rightly holds that phagocytosis is of chief importance from the fact that typhoid bacilli liberate their endotoxin when dissolved by means of bacteriolytic serums.

4. In serious types in which the system is already overwhelmed with the typhoid bacillus and its toxins. it is unwise to employ the vaccine treatment, for it may be a source of fresh danger. Under these circumstances, there can be no response to attempts at stimulating the production of immunizing sulstunces by the introtuction into the system of more of the specific poison. On the contrary, there must occur an aggravation of the symptoms.

5. When typhoid fever is being treated with raceines the determination of the opsonic index in routine private practice is too time-consuming a procedure to be

* Read in the Section on Pluarmacology and Therapeutics of the American Aodical Associntion, ut the Sixty-flist Annual Session. held at St. Louis, June, 1010.

cld at St. Louls, June, 1010. Whansehr, Oct, 12, 1893.

2. Rtchardson, M. W.: Vucelne Thorupy: General Princlples, Tru Jolksa, A. M. A., Jan. 2.2, 1910, p. 2.5.

3. Emery : Immunity and specifjc ilierapy, p. 388. adopted, although desirable, when it can be carried out, in hospital work. Fortunately, it is generally conceded to be unnecessary to estimate the opsonic index, if the effect of the treatment on the general clinical symptoms be closely observed.

6. 'Typhoid fever is an acute bacteriemia plus toxemia, often fulminating in character, and not a localized infection; hence, brilliant results from the vaccine treatment for the cure of this disease are scarcely to be expected.

It may be questioned seriously whether, on account of the foregoing facts, it is not injudicions to practice vaccine therapy in the severer and so-called malignant types of typhoid fever. In this connection, it should be recollected that chronic infections in which the sperific organism is, more or less, completely walled off from the general circulation, with slow absorption of toxins into the blood are those in which the vaccine therapy gives its best results. Here, the production of antibodies can be stimulated "by the introduction of dead bacilli into the general circulation, and these can effectually exercise their therapeutic properties on the bacteria in a chronic lesion" (Swan).

$\Lambda$ considerable number of clinical observers have been impressed with the curative or controlling influence of proper inoculations with appropriate bacterial vaccines in typhoid fever. One of the earliest observers, Captain Smallman, ${ }^{4}$ employed the method in thirty-six cases with three deaths or a percentage of 8.3. He remarks especially on the absence of prolonged cases, of complications, of sequele and of relapses; and, further, that a local infection during convalescence, for example, periostitis of the tibia, can be dissipated by the local injection of vaccines. From an olservation of forty cases, Watters and Eaton" suggest that the early administration of typhoid vaccine appears to shorten, in many cases, the duration of the disease and to cause the affection to run a mild course. Semple ${ }^{0}$ treated nine cases, six of which showed well-marked improvement after the inoculations, especially two cases treated with autogenous vaccines. In the remaining three, amelioration of the symptoms occurred.

On the other hand, certain wuiter's, who have had much experience of the use of vaccines in the treatment of typhoid fever, declare that the results are not especially striking, while others have found them to be practically negative. For example, J. B. Nichols tried the inoculation method in the Freedmen's Hospital, but "no effect on the clinical conditions, in the way of eithei improvement or aggravation of the symptoms, was definitely demonstrable." Richardson ${ }^{2}$ reported the results

\footnotetext{
4. Smullmnn: Tour. Roy. Army Med. Corps, London, 1009 xil. ${ }^{4}$ ish.

5. Watters and Faton: Boston Med. and Surg. Jour., April 22 (6.

6. Semple: Lancet, London, 1909, 1f, 1608.
}

7. Nichols, J. B.: Washington Med. Ann., November, 1000, p. 293. 
of the method in twenty-five ases of typhoid fever without encouraging effects. He, however. asserts that the influence of inoculation is lavorable in preventing, in large measure at least. typhoirl relapses when its use is continued during the period of convalesence. Emery remarks that the curative treatment of typhoid lever by vaceine therapy is not satislactory and is still on trial, althongh he almits that promising results have been obtained by some olservers.

In eight ases, reported in this paper, small doses of raceine were employed, namely, initial doses of 25 millions, and subseguent ones of 50 millions ench. further consileration. It is clear, if the foregoing premises be correct, that an increased production of polynuclear leukocytes must stimulate, to a corresponiing extent, the phagocytosis of the intruding organisms of this disease. But though my own observations, which are too few to warant generalization. show that small doses of vaceines do not, to any appreciable degree, stimulate phagocytosis during trphoid ferer, it is desirable also, to note effect of larger doses.

Finally, it must be conceded that in the complicated process of active immunization, other, although doubtless minor, factors enter. For cxample. Nuttal and other observers found that "hacteria underwent changes inclicative of death and destruction before they were taken up by the phagorytes" (Fmery). It will not be denied that scrum is an aid to phagocytosis by its action on the bacteria: hence opsonins are believed to be specific antibodies.

Granted that active immunity in typhoid fever is brought about mainly by an increase in opsonins circulating in the blood, it must be recollected, as pointed out above, that hacteriolytic antibodies set free the endotoxin of the tiphoid bacilli, and hence may be a source of added danger. Under these circumstances, bacteriolytic serums can searcely be regarded as Nature's means of establishing inmmunity.

Fig. 1.-Temperature churt, case of B. M., illustrating effect of vaccine treat ment in typhoid fever.

These were repeated at intervals of seventy-two hours, as a rule. According to some witers, a safe and useful initial dose is 300 to 350 millions of organisms; this sometimes produces a reactionary rise of temperature to $105 \mathrm{~F}$. In my view, massive doses should not be employed in the milder forms of typhoid fever for the reasons previously adduced.

In my series of eight cases, in all save one of which the Widal reaction was present, a reactionary fever did not occur, but in two instances (Charts 1 and 2), the nocturnal remissions of temperature became distinetly greater immediately after the use of the vaceines, and in one instance of protracted subfebrile temperature due to typhoid fever, it would seem that they were sufficiently powerful to cause a gradual decline of temperature to the normal in the course of several days. In a case of prolonged and exhausting illness, the patient apparently making no progress toward recovery, Ramsburgh, on the advice of $\mathrm{Nichols,} \mathrm{used} \mathrm{a} \mathrm{vac-}$ cine with definitely fuvorable results. Ruffin ${ }^{\circ}$ las reported a case of typhoid fever with prolonged course, in which the injection of 800 million bacilli produced a sharp febrile reaction, followed by subsidence of the pyrexia. In one of my cases a relapse oceurred.

$A$ blood eximination in my series of cases before injection of raccines and another twenty-four hours thereafter, gave an average result, as shown in the accompanyind table.

In view of the fact that plangocytosis most probahly plays a principal rôle in Nature's methol of rulung typhoid fever, the question of the effect of vaceines on the leukocrte count shomld not ho ignored. I am not aware that this aspect of the subject has been investigater hitherto, lut it seems to me to be one quite worthy of



9. Kulle: Washlngion Med. dnu., 19u9, vil, 77.
If, however, as before stated, the process of immunization is dependent rhiefly on phagocytosis, and if it be shown that the vaceines stimulate the bone marrow to an increased production of leukocrtes, and, through chemotaxis, also, cause an increased output of these cells, then vaccine therapy is to be advised and encouraged.

'The mobilized defensive fores in a case of typhoid fever, however, would seem to center about phagocytosis. In this commection, the fact that leukopenia exists in

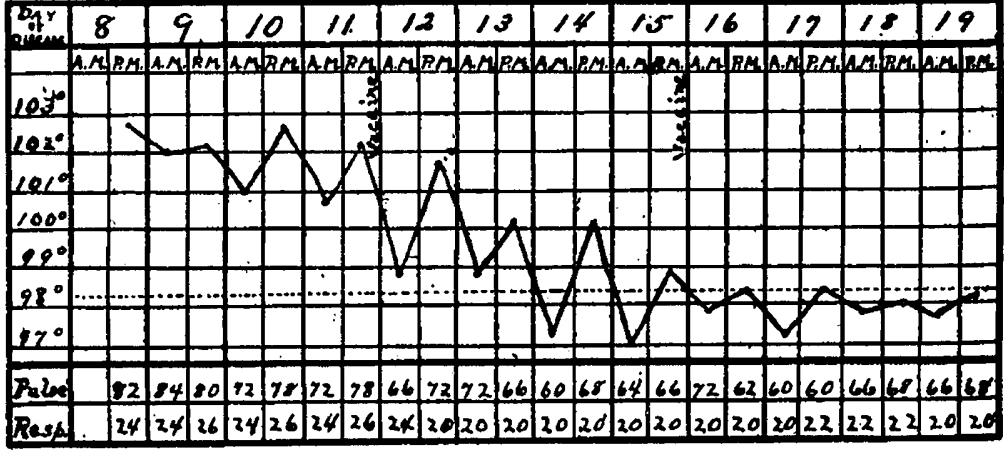

Fig. 2.-Temperature chart, case of L. W, Hustrating effect of vacelne treat ment in typhold fover.
TAIBIE OF BIOOD IEXAMINATION

\begin{tabular}{|c|c|c|c|c|c|c|}
\hline \multirow[b]{3}{*}{ Loukorytos } & \multicolumn{2}{|c|}{ _Lase 1 - } & \multicolumn{2}{|c|}{ - Case 2-_- } & \multicolumn{2}{|c|}{$\ldots$ Cnse 3 - } \\
\hline & I3efore. & Aitur. & Before. & After. & lefore. & After. \\
\hline & $6,400)$ & $T, 2(0)$ & 9,800 & 7,000 & 6.800 & 6.800 \\
\hline lolynucloar & 54.0 & 51.0 & $5 \times .0$ & (i1.0 & (io.0 & $(; 2,0$ \\
\hline Small lymphocytes & 20.0 & 28.0 & 28.0 & 34.0 & 94.0 & 18.1 \\
\hline lymphocytes & 14.0 & 15.0) & 9.0 & 3.0 & 11.0 & 18. \\
\hline 'lvasitional & $3 . \overline{3}$ & 3.0 & 4.0 & 2.0 & 2.0 & \\
\hline \multirow[t]{3}{*}{ Eosinophlls....... } & 1.5 & 2.0 & 1.0 & $\ldots$ & $\cdots$ & \\
\hline & $-C_{t}$ & (e) $4-$ & $-(\mathrm{M}$ & 5 & - Case & 6 \\
\hline & Bofore. & Alter. & IBefore. & Aftor. & Before. & After. \\
\hline Leul & 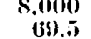 & $7, \frac{10}{70}$ & $\begin{array}{l}71.5 \\
7100\end{array}$ & $\begin{array}{r}6,9-40 \\
(j 4.2\end{array}$ & $\begin{aligned} 7,3(30) \\
7 \div .0\end{aligned}$ & $\begin{array}{l}7,84 \\
68 .\end{array}$ \\
\hline יון & 2.0 & 1. & 3.0 & 2.0 & 2.0 & 3 \\
\hline $\mathrm{Tr}$ & 2.0 & 2.0 & 1.0 & 3.1 & 1.0 & B. \\
\hline Lymphocytes & $20 . \overline{0}$ & 26.9 & 24.5 & 30.7 & 20.0 & 25 \\
\hline
\end{tabular}


uncomplicated typhoid fever is to be recollecter. At all events, in view of the foregoing facts, the use of vaccines in the treatment of this disease should be somewhat restricted according to conditions and indications mesented by individual eases. Their routine nse, however, is not to be encouraged, but it is obvious that an anti-endotoxin serum would, by neutralizing the soluble endotoxins, constitute the jdeal method of treating typhoid fever. Such a serum has been preparer by MacFadyen, and favorable results have already been reported from its use, when administered early in typhoid cases. It is not improbable that the vaccine treatment of typhoid fever, except as indicated below, will give place to the method of establishing passive immunity by means of an anti-enclotoxin. In view of the marked discrepancy among clinical observers as to the size and repetition of the doses, there would seem to be great necessity for an especial consideration of these aspects of the question of therapeutic inoculations in the future.

Faccine therapy in the treatment of typhoid fever. however, should receive a more extenderl trial than hitherto, more particularly in the carlier stages of mild types of the disease, before being rojected. Finally, in the present state of our knowlelge, the value of vaccines for the following purposes must be conceded: (1) as a means of prophylaxis; (2) in suitable cases when continued during convalescence, to prevent relapses; (3) to combat local infections with the typhoid hacillus, as for example, bone suppurations which arise in the period of convalescence, and (4) for the removal of the typhoid bacilli from the feces and urine in the case of typhoid-carriers. ${ }^{10}$

I desire to express my thanks to Dr. A. A. Stevens, who at my suggestion, treated three of the cases reported above with the results of bloor examinations before and after the inocu. lations, in the wards of the Protestant Fpiscopal Hospital of Philadelphia, and to Jr. Robert B. Walker for furnishing one of the cases belonging to my series from the Philadelphia Hospital.

1605 Wainut Street.

\section{THF FUNDAMENTAT PRINCIPIES TTNDER- LYING THE TREATMENT OF WOUNDS ON THE BODY SURFACE}

\section{CHAUNCEY E. TENNANT, M.D.} DENVER

Steadily through the maze of a multiplicity of methods, there has crystallized the present treatment of surface traumatic lesions. Based on the knowledge of definite pathologic and histologic processes and confirmed by the shorter periods of disability and lessened distortion of function, modern treatment of surface injuries may be reduced to two fundamental principles: moist hyperemia and the open-air treatment; in other words, the use of a dressing capable of giving sustained heat and moisture, or one so constructed that it will not displace the protective covering of congulated serum, yet will protect the wound from further lamage.

The wide latitude of pathologic possibilities in surface lesions, varying as they do from a microscopic skin puncture attencled with violent constitutional toxemia and death, on the one hand, to extensive abrasions and lacerations with no constitutional manifestations on the

10. Irwin, S. 'Y., and Ilouston, T.: Lancet, London, Jan. 30, 1009, p. 311. other, has, in a measure, justified any course which has had as its result a satisfactory functional termination.

Until recently, little thouglit was given to the indiviclual factor of lowered inderial resistance, or the influence of the genernl state of nutrition on cell-regeneration. But now, with the more careful and detailed consideration of the possibilities of lowered resistance and cell nutrition, there has been a stimulus for the introduction of methods calculated either to intensify locally, or to increase, the number of antibactericidal bodies at the varjous parts of the organism where needed, or to engrorge the tissues with nutritive plasma for the revitalization of the traumatized cell.

Surface lesions of the body widely differ in character, as burns, incised or crushing wounds, etc., and they may also vary from the small pin-point puncture to the extensive loss of continuity which is limited only by the size and force of the destructive agent. But so far as

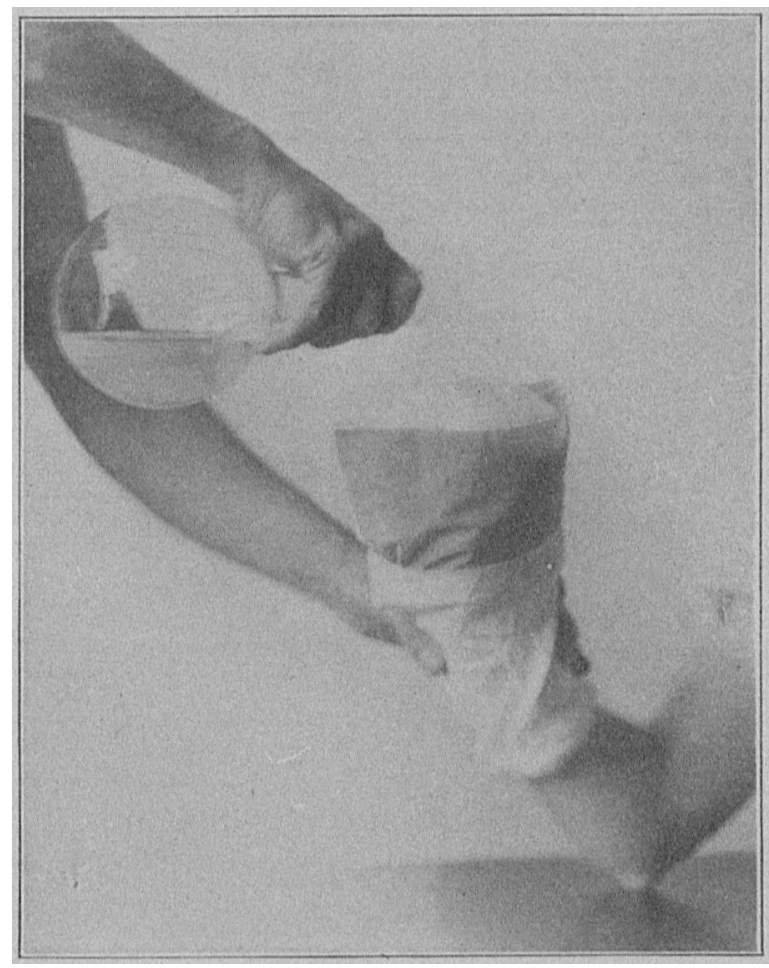

Fig. 1.-Method of applying large and coplous wet dressings.

the end-results are concerned, the only difference is their type and degree of infection. Therefore the plan of treatment must be carly outlined, if the most successful results are to be obtained. It is well known that in burns, skin-grafts and other superficial traumas which remain sterile, the dry method of treatment gives the most satisfactory results both as to convalescence and function, while the moist hyperemia is the treatment especially adapted to infected wounds, where the organism has lodged itself in the subcutaneous tissues and lymphatics.

As a rule, the infection is either of the staphylococeic or streptococeic type; the former invariably localizes in a small urea, while the latier is most likely to lodge in the subcutancous tissues and extend rapidly along the lymplaties. Where resistance is fair and early excited, the chemotactic disturbance is quickly manifested with temperature and other clinical phenomena of inflammation. In either type of infection, it is extremely impol- 